\title{
Does Access to Rural Credit Help Decrease Income Inequality in Brazil?
}

\author{
Mateus de Carvalho Reis Neves ${ }^{1, \star(B)}$, Carlos Otávio Freitas ${ }^{2}$, Felipe de Figueiredo Silva ${ }^{3}$, \\ Davi Rogério de Moura Costa ${ }^{4}$ and Marcelo José Braga ${ }^{5}$ \\ ${ }^{1}$ Federal University of Viçosa, Edson Potsch Magalhães Building - Purdue St, Campus Universitário, Viçosa, MG 36570-900, \\ Brazil, ${ }^{2}$ Federal Agricultural University of Rio de Janeiro-RJ, BR 465 Rd, Km 07, Seropédica, RJ 23890-000, Brazil, ${ }^{3}$ Clemson \\ University, 235 McAdams Hall, Clemson, SC 29634, USA, ${ }^{4}$ School of Economics Business Administration and Accounting at \\ Ribeirão Preto, University of São Paulo (FEA-RP/USP), 3900 Bandeirantes Ave., sala 42 - Bloco B2 FEA-RP, Ribeirão Preto, SP \\ 14040-905, Brazil and ${ }^{5}$ Federal University of Viçosa, Edson Potsch Magalhães Building - Purdue St, Campus Universitário, \\ Viçosa, MG 36570-900, Brazil \\ *Corresponding author. Email: mateus.neves@ufv.br
}

\begin{abstract}
Agricultural production in Brazil has increased in recent decades. Despite this, the rural population continues to face income inequality. Policies targeting this issue, such as rural credit, have been implemented during this period. This study estimates the influence of credit on income inequality in Brazilian rural areas. Results suggest that the family farming credit program (PRONAF) is not associated with increase in inequality. However, access to rural credit from sources other than PRONAF has led to greater household income inequality. Results also indicate that greater levels of education and access to rural extension have boosted the effect of credit on income.
\end{abstract}

Keywords: Decomposition of income differentials; Income inequality; PRONAF; Rural credit; Unconditional quantile regression JEL Classifications: Q12; O15; C31; R58

\section{Introduction}

Brazil has increased agricultural production in recent decades and has engaged in stronger participation in the global market. In spite of increased production, rural populations continue to deal with high-income inequality. Commercial agricultural production remains concentrated in large farms, with approximately $85 \%$ of gross agricultural income being generated by $11.4 \%$ of Brazilian farms (Alves et al., 2013). Barros et al. (2006) and Helfand et al. (2009) found evidence of great inequality in rural areas of Brazil using the Gini index. Although income inequality has decreased over time, much remains to be done in order to achieve lower levels of income inequality.

Several factors could contribute to a more equal income distribution in rural areas, including access to rural extension and financial markets. The Brazilian government has implemented several public policies aimed at decreasing income inequality. These policies were based on programs such as income transfer, pension, and credit, but they have shown only a modest contribution to the decrease of rural income inequality (Barros et al., 2006; Soares, 2010; Batista and Neder, 2014).

In 1965, Brazil created the National Rural Credit System (SNCR) to enhance agricultural production and improve the living standards of rural households. The National Agricultural Policy, created in 1991, also contributed to income generation in rural areas of Brazil. Although these instruments sought to improve rural income distribution, they have obtained questionable 
outcomes. Vega (1987), Bacha, Danelon and Belson (2005), and Araújo (2011) found that large farmers are obtaining greater benefit from access to credit than small farmers.

To overcome inequality in the distribution of benefits, the Brazilian government created the Program for the Strengthening of Family Farming (PRONAF) in 1995. This program seeks to stimulate income generation for small farms that face low productivity and are unable to obtain inputs to modernize their farm and increase productivity (Guanziroli, 2007; Santana et al., 2014). However, Corrêa and Silva (2004) and Guanziroli (2007) also suggest that this program is not achieving its initial goal of decreasing inequality.

We have observed a consensus in the literature indicating that, although Brazil has improved rural household access to financial markets (also represented in access to credit), income inequality in these areas remains high and the policies established to combat inequality have been benefiting larger farms. The literature lacks research identifying the additional factors contributing to reductions in rural inequality, such as rural extension, which boost the effect of credit on household income. The literature also lacks analyses that break down the effect of credit on income by income quantiles (e.g., access to credit might have a stronger effect on income in households with a higher income compared to those with a lower income). In this paper, we address these two major limitations by estimating the effect of credit on household income in rural areas of Brazil.

To determine the influence of credit on household income, we use an income decomposition proposed by Firpo et al. (2007) and the household survey of 2014 from the IBGE (National Household Sample Survey-PNAD). This approach consists of two steps. First, we estimate income regressions for different unconditional quantiles of the income distribution. Second, the income differential is then decomposed into return and composition effects to identify the main factors that explain the income gap across all analyzed quantiles. In addition to this decomposition, we also identify additional factors that are important to the effectiveness of this policy, such as farmer schooling and access to rural extension. Notably, this analysis would be very helpful for guiding the design of new public policies seeking to integrate different agricultural policies such as PRONAF and rural extension.

Our results suggest that credit has led to higher household income inequality in rural areas of Brazil. We determined that households within higher income quantiles observed greater benefits from accessing credit compared to those in lower quantiles. Households that have also had access to rural extension observe more benefits from accessing credit contracts. This combined effect of credit extension is higher among households in the top income quantiles. These results indicate that the coordination of public policies on access to credit and rural extension simultaneously would result in higher benefits to households in rural areas.

\section{Background}

In Brazil, public policies on rural credit took shape in 1965 with the National Rural Credit System (SNRC). The SNRC was in charge of operating the rural credit policy, which was considered one of the main pillars to agricultural modernization (Santana et al., 2014). Overall, these policies aimed to create structural changes to national agriculture. Public policies in rural credit have undergone three distinct phases between 1969 and 2012 (Buainain et al., 2014). In the first phase, between 1969 and 1979, the total volume of credit granted to producers and cooperatives grew substantially in real terms, from R $\$ 32$ billion to $\mathrm{R} \$ 161$ billion ${ }^{1}$. In the second phase, between 1979 and 1996 (during the Brazilian government debt crisis), fiscal reforms and stabilization plans led to a decrease in the supply of credit, registering the lowest value of R\$ 23 billion in 1996. Total credit supply increased gradually in the third phase, reaching R\$115 billion in 2012.

Rural credit has been used as one of the main instruments to incentivize agricultural production (Alves, 1993; Bacha, Danelon and Belson, 2005; Araújo, 2011; Garcias and Kassouf, 2016).

${ }^{1}$ Average exchange rate in 2014, R\$3.22/US\$. 
However, it has generated larger benefits to larger farms mostly because these farms have also received access to other services and better production inputs. In 1995, the PRONAF, also connected to the SNRC, was created to provide credit to small farms.

Family-owned farms are predominantly small farms that play an important role in the Brazilian economy. They represent more than $70 \%$ of rural establishments and generate $38 \%$ of the total value produced in agriculture (IBGE, 2017). In order to have access to credit from PRONAF, family-owned farms must fall within certain eligibility categories highlighted in the Declaration of Aptitude (DAP) to PRONAF Eligibility. The DAP states the maximum and minimum annual income from agricultural activities, property size, land tenure type, and residency in/near to rural property (BNDES, 2015). The supply of credit using this instrument has continuously increased since its creation. In its first year, PRONAF provided 307,000 contracts and R \$ 543 million in total loans, while 1.8 million contracts were signed using this instrument- totaling R $\$ 15.3$ billion - in 2012. Notably, the number of contracts nearly doubled in the 2015/2016 crop season (Araújo, 2011; Grisa et al., 2014; Bianchini, 2015).

\subsection{Income inequality and rural credit}

Several studies have investigated the determinants of income and income inequality in rural areas of Brazil while considering aspects related to rural credit access. Ferraz et al. (2008) used 2007 data from the Ministry of Finance and the direct comparison method. They concluded that both microcredit policies and lower interest rates correspond to an effective instrument for incentivize investments in productive activities and mitigate poverty. Notably, these instruments are effective when applied to low-income farmers. Batista and Neder (2014) also investigated the effects of PRONAF on rural poverty in Brazil between 2001 and 2009. They assumed that this instrument does not affect rural poverty directly but does affect the variation of income and/or the variation in income inequality. They used the PNAD database and data from the Central Bank of Brazil in a dynamic panel approach. They determined that PRONAF spending tends to indirectly reduce poverty by raising average income and reducing income concentration.

Souza et al. (2013) analyzed the inequality in PRONAF's credit distribution across the country using a descriptive approach and data from the Central Bank of Brazil. They found that, in the initial phase of the program, there was a strong increase in the number of contracts, which continued until 2006 and was followed by an increase in the average size of contracts. They also observed an increase in the participation of states with more capitalized agriculture. An analysis of the evolution of the program has shown that the distribution of credit in Brazil is unequal. However, Kageyama (2003) used field survey data from eight Brazilian states in 2001 and applied a multiple regression analysis to compare PRONAF borrowers and non-borrowers, finding no evidence of a positive effect of access to credit on household income, poverty reduction, or educational advancement among family-owned farms. Feijó (2001) also found a similar result, which indicated that farms with access to the program exhibited lower productivity growth compared to the control group.

Previous studies also investigated the effect of credit on income in other countries. Wan and Zhou (2005) investigated the determinants of income inequality in rural China using a regressionbased decomposition framework. They concluded that geographic location has been the dominant factor explaining inequality. They found that the most significant determinant of income inequality is the input capital. Mahjabeen (2008) examined the welfare and distributional implications of microfinance institutions in Bangladesh using a general equilibrium framework and found that microcredit increased the income and consumption levels of households, reduced income inequality, and enhanced welfare. Luan and Bauer (2016) examined the heterogeneity of rural credit effects in Vietnam using a data set of 1,338 households collected from the Vietnam Access Resources Household Survey in 2012. They used propensity score matching to evaluate this issue 
and found that access to credit had a positive effect on household income among households with higher income and access to large amounts of credit.

\section{Empirical strategy}

To estimate how access to credit affects (not in a causal way) household income, we use the National Household Sample Survey (PNAD) for 2014 from the IBGE ${ }^{2}$. This survey also provides a supplementary questionnaire that includes questions related to the access to and sources of credit for rural production. This survey categorizes rural credit into (i) PRONAF and (ii) other sources (i.e., other public programs and/or banking loans for rural usage). These questions were used to build dummy variables as a proxy for whether or not the farmer had access to rural credit.

Our data set is a subsample of the PNAD, which includes rural households only. Similar to Ely et al. (2017), our sample considers rural producers that are (i) economically active; (ii) employers or self-employed workers (these being the individuals interviewed in the questionnaire); and (iii) mainly occupied by agricultural activity. Our sample also included a small portion of rural property managers that live in urban areas (IBGE, 2017). After excluding missing values and outliers, the final sample consisted of 15,402 individuals.

Our dependent variable is monthly household income in R\$ (Reais-Brazilian currency), which is a proxy for farmer income. To control for other factors that also influence household income level, we also included:

a) gender: a dummy variable equals 1 if the individual is male;

b) race: a dummy variable equals 1 if the individual is black;

c) schooling: several dummy variables split into the categories "does not read and write," "incomplete elementary school," "complete elementary school," "incomplete high school," "complete high school," "incomplete higher education," and "complete higher education"; additionally, we also used the number of study years;

d) age: several dummies, distributed in "up to 25 years," "Age 26 to 35 years," "Age 36 to 45 years," "Age 46 to 55 years," "Age 56 to 65 years," and "Age 65 years or higher";

e) rural: a dummy variable equals 1 if the individual resides in a rural area;

f) extension: a dummy variable equals 1 if the individual has received technical assistance and rural extension from a private or governmental source;

g) land ownership: several dummy variables seek to identify the condition of the producer in relation to the land, such as whether the producer is a partner, tenant, occupant, owner, or another condition;

h) farm size: four dummy variables represent farm size, which are divided into very small (up to 10 hectares [ha]), small (10-100 ha), medium (100-1,000 ha), and large (> 1,000 ha);

i) regions: five dummy variables represent Brazilian macro regions-North, Northeast, Southeast, South, and Midwest.

Descriptive statistics are displayed in Figure 1 and Table 1 by credit access group. In our sample, approximately $13 \%$ of rural households had access to credit in 2014, of which $75 \%$ were from PRONAF. This percentage is similar to that verified by the Central Bank of Brazil, thus demonstrating the validity of PNAD for rural credit data (BCB, 2019).

Rural households that had access to credit exhibited a higher average monthly household income ( $\mathrm{R} \$ 4,019.00)$ compared to households that did not have access ( $\$ 2,286.00)$. Moreover, we observed

\footnotetext{
${ }^{2}$ According to Araújo et al. (2008), the National Household Survey is a unique survey conducted annually and nationwide that raises a variety of information regarding the Brazilian population's well-being and setting. Thus, it is a major source of data on the Brazilian social environment. In addition, it represents the most up-to-date individual-level database available for the Brazilian agricultural sector.
} 


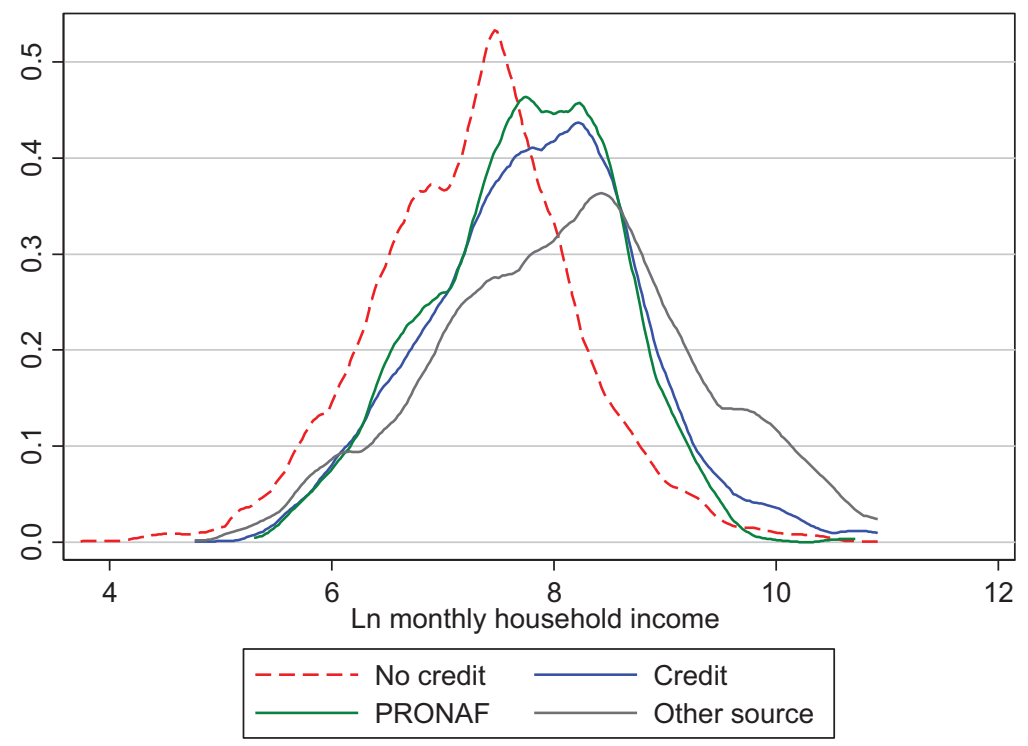

Figure 1. Monthly household income density distribution: no credit access, credit access, PRONAF, and credit from other sources, Brazil, 2014.

Source: Own elaboration based on PNAD 2014 (IBGE, 2017).

a high level of heterogeneity in household income, as evidenced by the standard deviation. Households with access to credit exhibited a higher education level and access to rural extension. Over $80 \%$ of the sample is male, with $73 \%$ living in rural areas and $75 \%$ owning the property.

Households that had access to credit from other sources exhibited a $50 \%$ higher income compared to households that had access to credit from PRONAF only. These households also exhibited a higher level of education and greater access to extension services. The majority of households had access to credit in the South of Brazil (35\%), followed by the Northeast (24\%). A similar pattern was observed upon analyzing credit from PRONAF, with South of Brazil accounting for $39.7 \%$ of households, followed by the Northeast with $22.6 \%$. Approximately $37 \%$ of households in our sample were in the Northeast.

We used this data set to determine the effect of rural extension on household income. First, we used the unconditional quantile regression method to identify the effect of rural credit on different income quantiles in the Brazilian rural area according to the methods of Firpo et al. $(2007,2009)$. Second, we identified household characteristics that might generate income disparity in access to rural credit outcome.

\subsection{The unconditional quantile regression approach}

To identify the effects (not causally) of rural credit on rural income and income inequality, we used the unconditional quantile regression approach proposed by Firpo et al. (2009) and the concept of recentered influence function (RIF). The influence function ${ }^{3}$ facilitates identification of the relative effect (influence) of an individual observation on a statistic of interest (Silva and França, 2017). That is, for a distribution statistic $v\left(F_{y}\right)$, the influence of each observation on $v\left(F_{y}\right)$ is given by the influence function $\operatorname{IF}\left(y ; v, F_{y}\right)$. The incorporation of the statistic $v\left(F_{y}\right)$ in the influence function results in the so-called $\operatorname{RIF}, \operatorname{RIF}(y ; v)=v(y)+\operatorname{IF}(y ; v)$. This allows an analysis on

\footnotetext{
${ }^{3}$ The influence function method provides a linear approximation for a nonlinear function of a statistical distribution of interest, such as quantiles, variance or others, thus allowing an estimate of the effect of one or more covariates on the distribution of the statistics of interest (Chi and $\mathrm{Li}, 2008$ ).
} 
Table 1. Mean and standard deviation of the variables used for total sample and by rural credit group, Brazil, 2014

\begin{tabular}{|c|c|c|c|c|c|c|c|c|c|c|}
\hline \multirow[b]{2}{*}{ Variables } & \multicolumn{2}{|c|}{ Brazil } & \multicolumn{2}{|c|}{ No Rural Credit } & \multicolumn{2}{|c|}{ Rural Credit } & \multicolumn{2}{|c|}{ PRONAF } & \multicolumn{2}{|c|}{ Other Sources } \\
\hline & Average & SD & Average & SD & Average & SD & Average & SD & Average & $\overline{S D}$ \\
\hline Monthly household income (R\$) & 2,505 & 3,473 & 2,286 & 3,043 & 4,019 & 5,360 & 3,190 & 3,123 & 6,548 & 8,846 \\
\hline Gender & 0.855 & 0.352 & 0.848 & 0.359 & 0.905 & 0.293 & 0.903 & 0.296 & 0.913 & 0.282 \\
\hline Race & 0.0733 & 0.261 & 0.0778 & 0.268 & 0.0425 & 0.202 & 0.0476 & 0.213 & 0.0270 & 0.162 \\
\hline Study years & 5.588 & 3.988 & 5.410 & 3.951 & 6.817 & 4.034 & 6.452 & 3.775 & 7.929 & 4.563 \\
\hline Don't read and write & 0.00402 & 0.0633 & 0.00439 & 0.0661 & 0.00154 & 0.0392 & 0.00204 & 0.0451 & 0 & 0 \\
\hline Incomplete elementary & 0.223 & 0.416 & 0.239 & 0.427 & 0.112 & 0.316 & 0.116 & 0.320 & 0.102 & 0.303 \\
\hline Complete elementary & 0.518 & 0.500 & 0.515 & 0.500 & 0.536 & 0.499 & 0.570 & 0.495 & 0.434 & 0.496 \\
\hline Incomplete high school & 0.0843 & 0.278 & 0.0806 & 0.272 & 0.110 & 0.313 & 0.116 & 0.321 & 0.0892 & 0.285 \\
\hline Complete high school & 0.0329 & 0.178 & 0.0318 & 0.176 & 0.0405 & 0.197 & 0.0381 & 0.191 & 0.0477 & 0.213 \\
\hline Incomplete higher education & 0.107 & 0.309 & 0.101 & 0.302 & 0.143 & 0.350 & 0.122 & 0.328 & 0.205 & 0.404 \\
\hline Complete higher education & 0.0317 & 0.175 & 0.0280 & 0.165 & 0.0569 & 0.232 & 0.0354 & 0.185 & 0.122 & 0.328 \\
\hline Age 25 & 0.0537 & 0.226 & 0.0564 & 0.231 & 0.0359 & 0.186 & 0.0395 & 0.195 & 0.0249 & 0.156 \\
\hline Age $26-35$ & 0.150 & 0.357 & 0.149 & 0.356 & 0.156 & 0.363 & 0.144 & 0.351 & 0.191 & 0.393 \\
\hline Age $36-45$ & 0.218 & 0.413 & 0.219 & 0.414 & 0.214 & 0.410 & 0.214 & 0.410 & 0.212 & 0.409 \\
\hline Age $46-55$ & 0.261 & 0.439 & 0.256 & 0.436 & 0.299 & 0.458 & 0.301 & 0.459 & 0.295 & 0.456 \\
\hline Age $56-65$ & 0.206 & 0.405 & 0.205 & 0.404 & 0.213 & 0.410 & 0.231 & 0.422 & 0.158 & 0.365 \\
\hline Age 65 or higher & 0.110 & 0.313 & 0.114 & 0.318 & 0.0825 & 0.275 & 0.0701 & 0.255 & 0.120 & 0.326 \\
\hline Rural & 0.733 & 0.443 & 0.727 & 0.445 & 0.769 & 0.422 & 0.813 & 0.390 & 0.635 & 0.482 \\
\hline Extension & 0.141 & 0.348 & 0.0912 & 0.288 & 0.482 & 0.500 & 0.502 & 0.500 & 0.419 & 0.494 \\
\hline Partner & 0.0573 & 0.232 & 0.0606 & 0.239 & 0.0348 & 0.183 & 0.0381 & 0.191 & 0.0249 & 0.156 \\
\hline Tenant & 0.0531 & 0.224 & 0.0527 & 0.223 & 0.0558 & 0.230 & 0.0537 & 0.226 & 0.0622 & 0.242 \\
\hline Occupant & 0.0469 & 0.211 & 0.0514 & 0.221 & 0.0164 & 0.127 & 0.0156 & 0.124 & 0.0187 & 0.136 \\
\hline Owner & 0.754 & 0.430 & 0.742 & 0.438 & 0.842 & 0.365 & 0.835 & 0.372 & 0.863 & 0.344 \\
\hline
\end{tabular}




\begin{tabular}{|c|c|c|c|c|c|c|c|c|c|c|}
\hline \multirow[b]{2}{*}{ Variables } & \multicolumn{2}{|c|}{ Brazil } & \multicolumn{2}{|c|}{ No Rural Credit } & \multicolumn{2}{|c|}{ Rural Credit } & \multicolumn{2}{|c|}{ PRONAF } & \multicolumn{2}{|c|}{ Other Sources } \\
\hline & Average & SD & Average & SD & Average & SD & Average & SD & Average & SD \\
\hline Other condition & 0.0883 & 0.284 & 0.0935 & 0.291 & 0.0512 & 0.221 & 0.0578 & 0.233 & 0.0311 & 0.174 \\
\hline Very small & 0.600 & 0.490 & 0.628 & 0.483 & 0.405 & 0.491 & 0.424 & 0.494 & 0.346 & 0.476 \\
\hline Small & 0.262 & 0.440 & 0.239 & 0.426 & 0.421 & 0.494 & 0.465 & 0.499 & 0.288 & 0.453 \\
\hline Medium & 0.0704 & 0.256 & 0.0657 & 0.248 & 0.103 & 0.305 & 0.0483 & 0.214 & 0.272 & 0.445 \\
\hline Large & 0.0467 & 0.211 & 0.0466 & 0.211 & 0.0476 & 0.213 & 0.0381 & 0.191 & 0.0768 & 0.266 \\
\hline North & 0.269 & 0.443 & 0.284 & 0.451 & 0.166 & 0.372 & 0.154 & 0.361 & 0.201 & 0.401 \\
\hline Northeast & 0.378 & 0.485 & 0.397 & 0.489 & 0.241 & 0.428 & 0.226 & 0.418 & 0.288 & 0.453 \\
\hline Southeast & 0.114 & 0.317 & 0.111 & 0.314 & 0.131 & 0.337 & 0.121 & 0.326 & 0.160 & 0.367 \\
\hline South & 0.158 & 0.365 & 0.130 & 0.336 & 0.354 & 0.478 & 0.397 & 0.489 & 0.224 & 0.417 \\
\hline Midwest & 0.0657 & 0.248 & 0.0626 & 0.242 & 0.0871 & 0.282 & 0.0878 & 0.283 & 0.0851 & 0.279 \\
\hline \#Observations & \multicolumn{2}{|c|}{15,402} & \multicolumn{2}{|c|}{13,450} & \multicolumn{2}{|c|}{1,952} & \multicolumn{2}{|c|}{1.470} & \multicolumn{2}{|c|}{482} \\
\hline
\end{tabular}

Notes: SD, standard deviation; average exchange rate in 2014, R\$3.22/US\$.

Source: Own elaboration based on PNAD 2014. 
the effects of individual covariates on the statistical distribution of interest. While we are interested in the distribution of the quantiles, it can also be applied to different statistical distributions such as the Gini coefficient, variance, or others that represent income inequality ${ }^{4}$.

We define the $\tau$-th quantile $\left(q_{\tau}\right)$ of the income distribution $Y$ as $q_{\tau}=v_{\tau}\left(F_{y}\right)=\inf _{q}$ $\left\{q: F_{y}(q) \geq \tau\right\}$, and its influence function $I F\left(y ; q_{\tau}, F_{y}\right)$ as:

$$
\operatorname{IF}\left(y ; q_{\tau}, F_{y}\right)=\frac{\tau-1\left\{y \leq q_{\tau}\left(F_{y}\right)\right\}}{f_{y}\left(q_{\tau}\left(F_{y}\right)\right)}
$$

where $1\left\{y \leq q_{\tau}\left(F_{y}\right)\right\}$ is an indicator function that shows whether the variable $Y$ (monthly household income) is less than or equal to the quantile $q_{\tau}$, and $f_{y}\left(q_{\tau}\left(F_{y}\right)\right)$ represents the marginal density function of the distribution of $Y$ evaluated in $q_{\tau}$.

The RIF, which will replace the dependent variable $Y$ in the unconditional quantile analysis, is defined by the sum of the distribution statistics and their respective influence function, $R I F\left(y ; v, F_{y}\right)=v\left(F_{y}\right)+\operatorname{IF}\left(y ; v, F_{y}\right)$. Thus, adapting the expression to the $\tau$-th quantile $\left(q_{\tau}\right)$, the RIF for each income quantile is given by:

$$
R I F\left(y ; q_{\tau}, F_{y}\right)=q_{\tau}+\frac{\tau-1\left\{y \leq q_{\tau}\left(F_{y}\right)\right\}}{f_{y}\left(q_{\tau}\left(F_{y}\right)\right)}=c_{1 \tau} .1\left\{y \leq q_{\tau}\left(F_{y}\right)\right\}+c_{2 \tau}
$$

where $c_{1 \tau}=\frac{1}{f_{y}\left(q_{\tau}\right)}$ and $c_{2 \tau}=q_{\tau}-c_{1 \tau} .(1-\tau)$ and the conditional expectation is $v\left(F_{y}\right)$ (Firpo et al., 2009; Silva and França, 2017). This implies that

$$
E\left[R I F\left(y ; v, F_{y}\right)\right]=v\left(F_{y}\right)
$$

We first obtain the sample quantile $\hat{q}_{\tau}$ (Firpo et al., 2009; Koenker and Basset, 1978) and then the marginal density function $\hat{f}_{y}\left(\hat{q_{\tau}}\right)$ through kernel functions ${ }^{5}$. After obtaining these estimates, they are incorporated in equation (2).

We assume a covariate vector $X$ and the conditional expectation of the RIF as a function of $X$, that is, $E\left[R I F\left(y ; v, F_{y}\right) \mid X=x\right]$. Then, it can be represented as a linear regression in function of $X, R I F\left(y ; v, F_{y}\right)=X \beta+\varepsilon$. Assuming $E[\varepsilon \mid X]=0$ and applying the law of iterated expectations, we have the unconditional quantile regression:

$$
v\left(F_{y}\right)=E_{x}\left[E\left[R I F\left(y ; v, F_{y}\right)\right]\right]=E[X] \cdot \beta
$$

where $y$ represents the monthly rural household income; $\operatorname{RIF}\left(y ; v, F_{y}\right)$ is the RIF, which replaces the observed $y$ in each observation; $X$ is the vector of explanatory variables described in the previous section; and $\beta$ are the coefficients of interest, which capture the effect of changing the distribution of a variable on the unconditional quantile of $y$ or the unconditional quantile partial effect (Firpo et al., 2009). These coefficients can be estimated by ordinary least squares (OLS) or another linear estimator 6 .

\footnotetext{
${ }^{4}$ For an average, for example, $\mu\left(F_{y}\right)$, the influence function (IF) would be given by $\operatorname{IF}\left(y ; \mu\left(F_{y}\right)\right)=y-\mu\left(F_{y}\right)$, with the RIF specified as: $\operatorname{RIF}(y ; \mu)=\operatorname{IF}(y ; \mu)+\mu$. Firpo et al. (2007) present the RIF regressions for the case of the variance and Gini coefficient.

${ }^{5}$ According to Koenker and Basset (1978), the $\tau$-th quantile estimator of the marginal distribution of $Y\left(\hat{q_{\tau}}\right)$ can be defined as: $\hat{q_{\tau}}=\arg \min _{q} \sum_{i=1}^{N}(\tau-1\{Y i-q \leq 0\}) .(Y i-q)$. The density function of $Y$ is obtained by estimating the kernel density: $\hat{f}\left(\hat{q}_{\tau}\right)=\frac{1}{N \cdot b} \cdot \sum_{i=1}^{N} K_{y}\left(\frac{Y_{i}-\hat{q}_{\tau}}{b}\right)$, where $K_{y}(z)$ is a kernel function and $b$ is a positive scalar bandwidth. For more details, see Firpo et al. (2009).

${ }^{6}$ Firpo et al. (2009) present three possibilities of estimators: OLS, logistic estimator, and a non-parametric estimator-all with very similar results.
} 
The conditional quantile regression approach proposed by Koenker and Basset (1978) differs from the unconditional quantile regression proposed by Firpo et al. $(2007,2009)$ that is used in this paper. The former approach only allows us to estimate the "within-group"7 effect (Firpo et al., 2009), while the unconditional quantile regression allows us to estimate both "within-group" effect and "between-group" effect. The latter effect represents the influence of a given variable throughout the entire distribution.

\subsection{Decomposition of income differentials}

We use an income decomposition procedure proposed by Firpo et al. $(2007)^{8}$ to estimate the income differentials between groups: farms that have accessed rural credit and farmers that did not. It involves estimating the RIF regression along with a reweighting scheme proposed by DiNardo et al. (1996). It is an adaptation of the Oaxaca-Blinder ${ }^{9}$ decomposition approach, which allows us to expand the decomposition to other statistics of interest such as quantiles, variance, and Gini coefficient.

We assume two groups of households: $A$ (farmers that have accessed rural credit) and $B$ (farmers that have not accessed rural credit); a result variable $Y$ (logarithm of household incomes); and a group of covariates that represent individuals' characteristics. The decomposition seeks to identify the difference in income distribution of the two groups based on some statistics of these distributions as opposed to only analyzing the mean. This is represented as:

$$
\Delta^{v}=v\left(F_{y^{A}}\right)-v\left(F_{y^{B}}\right)
$$

where $v\left(F_{y^{t}}\right)$ represents a statistic of the income distribution (income quantiles, in this paper), for two groups $t=A, B$.

The term $\Delta^{v}$ is then divided into two components: difference in the observable individual characteristics (composition effect) and difference in coefficients between the two groups (return effect). To implement this decomposition, a counterfactual distribution $\left(F_{y^{c}}\right)$ must first be obtained in addition to its statistics of interest $v\left(F_{y^{c}}\right)$ such as in equation (4). This allows us to simulate an income distribution with characteristics of group $A$ and the returns (coefficients) to the characteristics of group $B$. We can insert $F_{y^{C}}$ in equation (5) to obtain:

$$
\Delta^{v}=\left[v\left(F_{y^{B}}\right)-v\left(F_{y^{C}}\right)\right]+\left[v\left(F_{y^{C}}\right)-v\left(F_{y^{A}}\right)\right] \Delta^{v}=\Delta_{R}^{v}+\Delta_{X}^{v}
$$

where the total income differential is decomposed into two terms: $\Delta_{R}^{v}$, which represents the portion of the differential resulting from the differences in the returns (coefficients) of the characteristics (return effect) and $\Delta_{X}^{v}$, which represents the portion of the differential associated with the differences in the distributions of the characteristics (composition effect).

To obtain equation (6), we re-estimate the RIF regressions for each of the groups and obtain the conditional expectation of the recentered functions of influence. This allows us to obtain the expected value of the RIF for the observed distributions $v\left(F_{y^{t}}\right)$ and the counterfactual distribution $v\left(F_{y^{c}}\right)$ in a linear specification:

$$
\begin{gathered}
v\left(F_{y^{t}}\right)=E\left[R I F\left(y^{t} ; v_{t}\right) \mid X, T=t\right]=X_{t} \beta_{t} \\
v\left(F_{y^{C}}\right)=E\left[\operatorname{RIF}\left(y^{C} ; v_{C}\right) \mid X, T=B\right]=X_{C} \beta_{C}
\end{gathered}
$$

\footnotetext{
${ }^{7}$ The result for each quantile depends on the $X$ characteristics of the individuals in that group and cannot be extrapolated to the other quantiles. It does not allow the analysis of the effect of a given variable on the entire $Y$ distribution.

${ }^{8}$ This method has been used in other studies, such as Machado and Mata (2005).

${ }^{9}$ For more details, see Jann (2008).
} 
for $t=A, B$. To obtain the parameters of interest $\beta$, Firpo et al. (2007) use a reweighting technique based on the study of DiNardo et al. (1996). The reweighting factors for each group are

$$
\begin{aligned}
& \omega_{A}(T)=\frac{T}{\hat{\rho}}, \\
& \hat{\omega}_{B}(T)=\frac{1-T}{1-\hat{\rho}} \text {, and } \\
& \hat{\omega}_{C}(T ; X)=\left[\frac{\hat{\rho}(X)}{1-\hat{\rho}(X)}\right] \cdot\left[\frac{1-T}{\hat{\rho}}\right]
\end{aligned}
$$

and

$$
\hat{\omega}_{C}(T ; X)=\left[\frac{\hat{\rho(X)}}{1-\hat{\rho}(X)}\right] \cdot\left[\frac{1-T}{\hat{\rho}}\right]
$$

where $T$ is either 1 or 0 and indicates whether the individual participates in group $A$ (value 1 ) or $B$ (value 0$) ; \hat{\rho}$ is an estimator of the probability that a farmer has accessed rural credit (group $A$, or $T=1$ ) given the characteristics vector $X$ and may be estimated using a probability model such as Logit or Probit (Chi and Li, 2008).

After obtaining the reweighting factors, the RIF regressions for each group can be estimated by OLS:

$$
\hat{\beta}_{t}=\left(\sum_{i \in t} \hat{\omega}_{t} \cdot X_{i} \cdot X_{i}^{\prime}\right)^{-1} \cdot \sum_{i \in t} \hat{\omega}_{t} \cdot \hat{R I F}\left(y^{t i} ; v_{t}\right) X_{i}
$$

for $t=\mathrm{A}, \mathrm{B}$ and for the counterfactual, the RIF is estimated as:

$$
\hat{\beta}_{C}=\left(\sum_{i \in A} \hat{\omega}_{C}\left(X_{i}\right) \cdot X_{i} \cdot X_{i}^{\prime}\right)^{-1} \cdot \sum_{i \in A} \hat{\omega}_{C}\left(X_{i}\right) \cdot \hat{R I F}\left(y^{A i} ; v_{C}\right) X_{i}
$$

where the decomposition presented in equation (11) can be obtained as:

$$
\hat{\Delta}^{v}=\left[\bar{X}_{B} \cdot \hat{\beta}_{B}-\bar{X}_{C} \cdot \hat{\beta}_{C}\right]+\left[\bar{X}_{C} \cdot \hat{\beta}_{C}-\bar{X}_{A} \cdot \hat{\beta}_{A}\right]_{\hat{\Delta^{v}}=\Delta_{R}^{v}+\hat{\Delta}_{X}^{v}}
$$

We can also identify the contribution of each covariate $X_{k}$, where $k=1, \ldots, K$, on each of the effects obtained in equation (12) as in:

$$
\begin{gathered}
\hat{\Delta}_{X}^{v}=\sum_{k=1}^{K}\left(\bar{X}_{c k}-\bar{X}_{A k}\right) \hat{\beta}_{A} \\
\hat{\Delta}_{R}^{v}=\left(\hat{\beta}_{B 1}-\hat{\beta}_{C 1}\right)+\sum_{k=2}^{K} \bar{X}_{B k}\left(\hat{\beta}_{B K}-\hat{\beta}_{C K}\right)
\end{gathered}
$$

where in equation (14), the first term (difference in the returns of the covariate $k=1$ ) represents the difference in the intercepts of the regressions of groups $A$ and $B$, while the second term represents the contribution of the return of each covariate in the total return effect. We used the codes rifreg and oaxaca 8 in Stata $14^{\circ}$. In the next section, we present the results obtained using the two methods. 


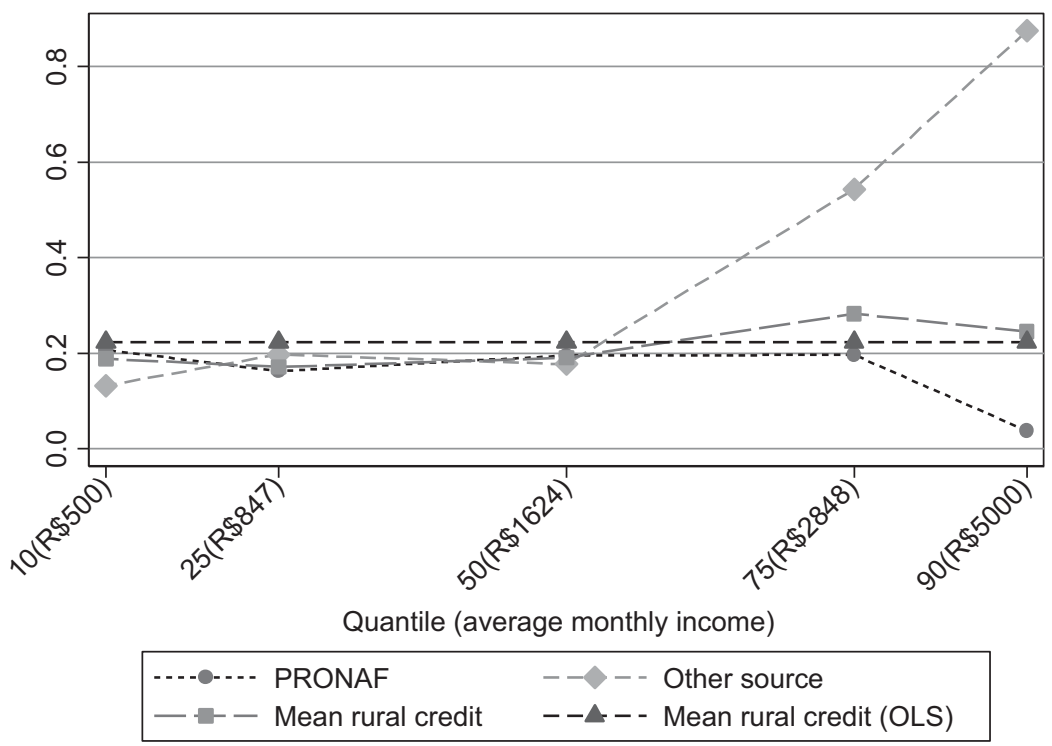

Figure 2. Effects of rural credit on the distribution of income in rural Brazil, 2014. Note: Average exchange rate in 2014, R\$ 3.22/US\$. Source: Own elaboration.

\section{Results}

In this section, we first present the results of the unconditional quantile regression followed by the results of the income decomposition. Finally, we provide a brief regional analysis of the decomposition of the income differential.

\subsection{Influence of rural credit on rural income}

In this section, we present the results of the RIF regressions for the unconditional income distribution quantiles of the logarithm of monthly household income and of the OLS. The estimated coefficients have shown some variations along the income distribution quantiles with respect to the estimated coefficients obtained for the mean (see Figure 2). This result re-enforces the need to use the unconditional quantile regression approach. Table 2 and Figure 2 present the results of RIF regressions for the unconditional income distribution quantiles of the logarithm of monthly household income. Our results suggest households in the bottom two quantiles (q10 and q25) that had access to credit are associated with an income $18.9 \%$ (i.e., R\$ 94.5 avg.) and $17.2 \%$ (i.e., R $\$ 145.68$ avg.) higher than those who did not. This behavior become stronger for the top two quantiles—q75 and q90-at approximately 28.3\% (i.e., R\$ 805.98 avg.) and $24.6 \%$ (i.e., $\mathrm{R} \$ 1,230.00$ avg.), respectively.

These results give us some indications that access to credit can be correlated with monthly household income and income inequality in rural areas of Brazil. It also makes us consider that access to credit is not achieving one of its intended goals. In Brazil, public policies on rural credit availability also aim to raise rural income by providing rural households with the opportunity to acquire more inputs, access new technologies, and reduce market imperfection effects (Alves et al., 2013; Leite, 2013; Hartarska et al., 2015; Garcias and Kassouf, 2016).

Variables capturing the effect of gender and race did not show different effects on household income quantiles. We only observed a difference at the bottom of the income distribution, where women have a higher income compared to men. Our results also suggest that household headed by 
Table 2. Estimates of unconditional quantile regression, Brazil, 2014

\begin{tabular}{|c|c|c|c|c|c|c|}
\hline Ln(Yi) Dependent Variables & OLS & $\mathrm{q} 10$ & q25 & q50 & q75 & q90 \\
\hline \multirow[t]{2}{*}{ Rural credit } & $0.224^{\star \star \star}$ & $0.189^{\star \star \star}$ & $0.172^{\star \star \star}$ & $0.191^{\star \star \star}$ & $0.283^{\star \star \star}$ & $0.246^{\star \star \star}$ \\
\hline & $(0.0206)$ & $(0.0311)$ & $(0.0282)$ & $(0.0240)$ & $(0.0346)$ & $(0.0578)$ \\
\hline \multirow[t]{2}{*}{ Extension } & $0.263^{\star \star \star}$ & $0.122^{\star \star \star}$ & $0.200^{\star \star \star}$ & $0.202^{\star \star \star}$ & $0.337^{\star \star \star}$ & $0.447^{\star \star \star}$ \\
\hline & $(0.0206)$ & $(0.0306)$ & $(0.0274)$ & $(0.0240)$ & $(0.0354)$ & $(0.0589)$ \\
\hline \multirow[t]{2}{*}{ Gender } & $-0.0611^{\star \star \star}$ & $-0.108^{\star \star}$ & $-0.193^{\star \star \star}$ & -0.0333 & -0.0220 & 0.0517 \\
\hline & $(0.0181)$ & $(0.0431)$ & $(0.0297)$ & $(0.0224)$ & $(0.0247)$ & $(0.0357)$ \\
\hline \multirow[t]{2}{*}{ Race } & $-0.0948^{\star \star \star}$ & 0.0450 & -0.0378 & $-0.153^{\star \star \star}$ & $-0.122^{\star \star \star}$ & $-0.106^{\star \star \star}$ \\
\hline & $(0.0259)$ & $(0.0634)$ & $(0.0448)$ & $(0.0309)$ & $(0.0298)$ & $(0.0359)$ \\
\hline \multirow[t]{2}{*}{ Incomplete elementary } & $-0.274^{\star \star \star}$ & 0.546 & $0.382^{*}$ & -0.206 & $-0.223^{\star}$ & 0.0125 \\
\hline & $(0.0151)$ & $(0.338)$ & $(0.197)$ & $(0.133)$ & $(0.125)$ & $(0.0599)$ \\
\hline \multirow[t]{2}{*}{ Complete elementary } & 0.0548 & $0.580^{\star}$ & $0.440^{\star \star}$ & -0.120 & -0.0591 & $0.214^{\star \star *}$ \\
\hline & $(0.114)$ & $(0.337)$ & $(0.196)$ & $(0.133)$ & $(0.125)$ & $(0.0588)$ \\
\hline \multirow[t]{2}{*}{ Incomplete high school } & 0.166 & $0.754^{\star \star}$ & $0.552^{\star \star \star}$ & 0.00850 & 0.112 & $0.405^{\star \star \star}$ \\
\hline & $(0.114)$ & $(0.338)$ & $(0.199)$ & $(0.135)$ & $(0.129)$ & $(0.0782)$ \\
\hline \multirow[t]{2}{*}{ Complete high school } & $0.308^{\star \star \star}$ & $0.778^{\star \star}$ & $0.695^{\star \star \star}$ & 0.0708 & $0.248^{*}$ & $0.655^{\star \star \star}$ \\
\hline & $(0.116)$ & $(0.346)$ & $(0.205)$ & $(0.139)$ & $(0.136)$ & $(0.107)$ \\
\hline \multirow[t]{2}{*}{ Incomplete higher education } & $0.407^{\star \star \star}$ & $0.721^{\star \star}$ & $0.738^{\star \star \star}$ & 0.202 & $0.310^{\star *}$ & $0.700^{\star \star \star}$ \\
\hline & $(0.119)$ & $(0.338)$ & $(0.198)$ & $(0.135)$ & $(0.129)$ & $(0.0797)$ \\
\hline \multirow[t]{2}{*}{ Complete higher education } & $0.509^{\star \star \star}$ & $0.825^{\star \star}$ & $0.731^{\star \star \star}$ & $0.392^{\star \star \star}$ & $0.971^{\star \star \star}$ & $2.062^{\star \star \star}$ \\
\hline & $(0.115)$ & $(0.337)$ & $(0.200)$ & $(0.136)$ & $(0.136)$ & $(0.143)$ \\
\hline \multirow[t]{2}{*}{ Age $26-35$} & $1.055^{\star \star \star}$ & -0.0319 & -0.0983 & $-0.133^{\star \star *}$ & $-0.0696^{*}$ & 0.0183 \\
\hline & $(0.120)$ & $(0.0902)$ & $(0.0610)$ & $(0.0407)$ & $(0.0397)$ & $(0.0606)$ \\
\hline \multirow[t]{2}{*}{ Age $36-45$} & -0.0514 & $0.177^{\star \star}$ & $0.118^{\star \star}$ & -0.0579 & -0.0135 & 0.0632 \\
\hline & $(0.0323)$ & $(0.0850)$ & $(0.0583)$ & $(0.0397)$ & $(0.0390)$ & $(0.0602)$ \\
\hline \multirow[t]{2}{*}{ Age $46-55$} & $0.0671^{\star \star}$ & 0.0564 & $0.157^{\star \star \star}$ & 0.00441 & 0.0409 & 0.0892 \\
\hline & $(0.0314)$ & $(0.0859)$ & $(0.0582)$ & $(0.0400)$ & $(0.0399)$ & $(0.0625)$ \\
\hline \multirow[t]{2}{*}{ Age $56-65$} & $0.0961^{\star \star \star}$ & $0.380^{\star \star \star}$ & $0.613^{\star \star \star}$ & $0.273^{\star \star \star}$ & $0.164^{\star \star \star}$ & $0.209^{\star \star \star}$ \\
\hline & $(0.0314)$ & $(0.0855)$ & $(0.0589)$ & $(0.0423)$ & $(0.0421)$ & $(0.0656)$ \\
\hline \multirow[t]{2}{*}{ Age 65 or higher } & $0.351^{\star \star \star}$ & $0.731^{\star \star \star}$ & $1.003^{\star \star \star}$ & $0.710^{\star \star \star}$ & $0.309^{\star \star \star}$ & $0.322^{\star \star \star *}$ \\
\hline & $(0.0327)$ & $(0.0847)$ & $(0.0585)$ & $(0.0451)$ & $(0.0482)$ & $(0.0731)$ \\
\hline \multirow[t]{2}{*}{ Rural } & $0.664^{\star \star \star}$ & $-0.218^{\star \star \star}$ & $-0.288^{\star \star \star}$ & $-0.229^{\star \star \star}$ & $-0.303^{\star \star \star}$ & $-0.333^{\star \star \star}$ \\
\hline & $(0.0357)$ & $(0.0316)$ & $(0.0239)$ & $(0.0186)$ & $(0.0222)$ & $(0.0342)$ \\
\hline \multirow[t]{2}{*}{ Partner } & $-0.0926^{\star \star \star}$ & -0.0319 & -0.00350 & $-0.185^{\star \star \star}$ & $-0.141^{\star \star \star}$ & $-0.113^{\star \star}$ \\
\hline & $(0.0278)$ & $(0.0652)$ & $(0.0493)$ & $(0.0341)$ & $(0.0370)$ & $(0.0528)$ \\
\hline \multirow[t]{2}{*}{ Tenant } & -0.0230 & -0.0586 & 0.0253 & 0.00830 & -0.0332 & -0.0435 \\
\hline & $(0.0274)$ & $(0.0657)$ & $(0.0456)$ & $(0.0336)$ & $(0.0413)$ & $(0.0621)$ \\
\hline
\end{tabular}


Table 2. (Continued)

\begin{tabular}{|c|c|c|c|c|c|c|}
\hline Ln(Yi) Dependent Variables & OLS & $\mathrm{q} 10$ & q25 & q50 & $\mathrm{q} 75$ & q90 \\
\hline \multirow[t]{2}{*}{ Occupant } & $-0.0579^{\star}$ & 0.0485 & -0.0409 & $-0.0801^{\star}$ & $-0.0573^{\star}$ & $-0.0932^{\star \star \star}$ \\
\hline & $(0.0339)$ & $(0.0835)$ & $(0.0639)$ & $(0.0415)$ & $(0.0347)$ & $(0.0349)$ \\
\hline \multirow[t]{2}{*}{ Other condition } & $-0.176^{\star \star \star}$ & $-0.341^{\star \star \star}$ & $-0.0957^{\star \star}$ & $-0.152^{\star \star \star}$ & $-0.178^{\star \star \star}$ & $-0.0994^{\star \star \star}$ \\
\hline & $(0.0231)$ & $(0.0681)$ & $(0.0438)$ & $(0.0291)$ & $(0.0264)$ & $(0.0360)$ \\
\hline \multirow[t]{2}{*}{ Small } & $0.222^{\star \star \star}$ & $0.234^{\star \star \star}$ & $0.216^{\star \star \star}$ & $0.175^{\star \star \star}$ & $0.270^{\star \star \star}$ & $0.266^{\star \star \star}$ \\
\hline & $(0.0157)$ & $(0.0299)$ & $(0.0237)$ & $(0.0191)$ & $(0.0238)$ & $(0.0357)$ \\
\hline \multirow[t]{2}{*}{ Medium } & $0.357^{\star \star \star}$ & $0.146^{\star \star \star}$ & $0.156^{\star \star \star}$ & $0.195^{\star \star \star}$ & $0.516^{\star \star \star}$ & $0.900^{\star \star \star}$ \\
\hline & $(0.0278)$ & $(0.0480)$ & $(0.0384)$ & $(0.0307)$ & $(0.0412)$ & $(0.0773)$ \\
\hline \multirow[t]{2}{*}{ Large } & $0.239^{\star * \star}$ & $0.197^{\star \star \star}$ & $0.208^{\star \star \star}$ & $0.164^{\star \star \star}$ & $0.208^{\star \star \star}$ & $0.398^{\star \star \star}$ \\
\hline & $(0.0322)$ & $(0.0519)$ & $(0.0469)$ & $(0.0405)$ & $(0.0514)$ & $(0.0832)$ \\
\hline \multirow[t]{2}{*}{ North } & $0.238^{\star \star \star}$ & $0.505^{\star \star \star}$ & $0.362^{\star \star \star *}$ & $0.200^{\star \star \star}$ & $0.176^{\star \star \star}$ & $-0.0597^{\star \star}$ \\
\hline & $(0.0197)$ & $(0.0379)$ & $(0.0293)$ & $(0.0207)$ & $(0.0210)$ & $(0.0252)$ \\
\hline \multirow[t]{2}{*}{ Southeast } & $0.472^{\star \star \star}$ & $0.578^{\star \star \star}$ & $0.540^{\star \star \star}$ & $0.489^{\star \star \star}$ & $0.484^{\star \star \star}$ & $0.259^{\star \star \star}$ \\
\hline & $(0.0199)$ & $(0.0411)$ & $(0.0324)$ & $(0.0265)$ & $(0.0335)$ & $(0.0493)$ \\
\hline \multirow[t]{2}{*}{ South } & $0.584^{\star \star *}$ & $0.599^{\star \star \star}$ & $0.600^{\star \star *}$ & $0.574^{\star \star \star}$ & $0.689^{\star \star \star}$ & $0.523^{\star \star \star}$ \\
\hline & $(0.0199)$ & $(0.0381)$ & $(0.0310)$ & $(0.0254)$ & $(0.0326)$ & $(0.0500)$ \\
\hline \multirow[t]{2}{*}{ Midwest } & $0.590^{\star \star \star}$ & $0.596^{\star \star \star}$ & $0.483^{\star \star \star}$ & $0.516^{\star \star \star}$ & $0.574^{\star \star \star}$ & $0.613^{\star \star \star}$ \\
\hline & $(0.0306)$ & $(0.0398)$ & $(0.0381)$ & $(0.0321)$ & $(0.0419)$ & $(0.0720)$ \\
\hline \multirow[t]{2}{*}{ Intercept } & $6.828^{\star * \star}$ & $5.184^{\star \star \star}$ & 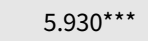 & $7.237^{\star \star \star}$ & $7.713^{\star \star \star}$ & $7.931^{\star \star \star}$ \\
\hline & $(0.118)$ & $(0.347)$ & $(0.204)$ & (0.139) & $(0.133)$ & $(0.0879)$ \\
\hline Observations & \multicolumn{6}{|c|}{15,402} \\
\hline$R^{2}$ & 0.079 & 0.161 & 0.227 & 0.242 & 0.172 & 0.079 \\
\hline F-statistic & 42.14 & 111.5 & 210.8 & 188.2 & 60.78 & 42.14 \\
\hline
\end{tabular}

Notes: ${ }^{* * *}$ significant at $1 \%$, ** significant at $5 \%$, ${ }^{*}$ significant at $10 \%$; standard errors in parentheses; Wald test indicated statistical difference, at a level of $1 \%$ of significance, between coefficients of covariates at different monthly income quantiles.

Source: Own elaboration.

black individuals observe lower incomes compared to other individuals. Experience, represented in this study by the age of the individual, has a stronger influence at the bottom of income distribution.

We found that variables related to a higher level of education ("complete elementary school," "high school," and "higher education") increased household income compared to the base variable ("people who cannot read or write"). Costa et al. (2016), Oliveira and Silveira Neto (2015), and Reis et al. (2017) have also identified positive effects of investments in human capital on income. We found that education can decrease income inequality, that is, great income returns to "high school" level in the bottom quantiles of the income distribution. Although "higher education" increases inequality, only $3.2 \%$ of the sample has a high education level.

As another public policy associated with agricultural production also observed in this sample, rural extension seeks to generate improvements to farm production and income by helping farmers to access new technologies and knowledge. This policy is traditionally connected with rural credit in Brazil. Our results suggest that access to rural extension is associated with higher income in all quantiles of the distribution. Along the top quantiles of the income distribution, q75 and 
q90, farmers that had access to rural credit obtained an income $34 \%$ and $45.5 \%$ higher than the others, respectively.

We found that farm ownership and living in urban areas might lead to higher household incomes. Farm owners have greater incentive to invest in innovations and long-term technologies that contribute to increased rural income. These farmers also have greater access to credit and other services, given that the land can be used as a tangible guarantee for the fulfillment of the financial obligations (Besley, 1995). Living in urban areas might lead to greater access to information regarding market input and output, banking institutions, and other services.

Results also suggest that the greater the farm, the greater the income, and that households in the South, Midwest, and Southeast regions are better off compared to households in the North and Northeast (base). These household differences have also been identified in the literature (Assunção and Chein, 2007; Souza, Ponciano, Ney and Fornazier, 2013; Oliveira and Silveira Neto, 2015; Costa et al., 2016).

Access to credit could affect household income differently by source, be it PRONAF or others. To illustrate that, we also estimated the equations disaggregating the variable credit in these two sources. Results are displayed in Table 3 and Figure 2 (which include the average household income per quantile).

These results have demonstrated that credit from other sources could be associated with higher rural income, namely by $54.4 \%$ (i.e., R\$ $1,549.31$ avg. in monthly household income quantile q75) compared to farmers that did not have access. It is relevant to point out that PRONAF's guidelines suggest that this line of credit is designed for low-income families. Also, credit from other sources might provide larger contract values than PRONAF ${ }^{10}$. Thus, comparisons of different sources of credit should consider this point. Access to PRONAF has a steady influence on household income (Figure 2) of approximately 0.2 and a non-significant effect on the top income quantile (due to the lower number of PRONAF borrowers). In summary, households in higher income quantiles experience superior improvements to their incomes when obtaining rural credit (not from PRONAF) compared to those in lower income quantiles. These results suggest the relevance of using the decomposition of income differentials to better understand the factors that explain such variations along the income quantiles.

\subsection{Decomposition of income differentials}

The data analysis indicates differences in the characteristics of farms with and without access to rural credit. The results presented in the previous subsection also indicate differences in the return to rural credit on income. In this section, we identify which factors explain this difference in income due to access to credit. The income decomposition method is used alongside the RIF regressions to evaluate how much of the income differences observed between the farm groups is attributed to the composition effect and return effect. The former effect represents differences in the distribution of the individuals' characteristics, while the latter represents differences in the returns of these characteristics. It allows us to identify the contribution of each explanatory variable on each of the estimated effects. The outcome of this methodology is presented in Table 4 and summarized in Figures 3, 4, and 5.

Rural households (farms) that had access to rural credit obtained a positive income gain in all the quantiles considered compared to farmers that did not have access to these services (Figure 3). Overall, the composition effect governs the income differential in the income quantiles q10 and from q50 and above. This implies that the differences in individual characteristics such as

\footnotetext{
${ }^{10}$ As an example, according to data from the Central Bank of Brazil, in the 2013/2014 crop season, average contract value of PRONAF was R $\$ 12,220.84$. In turn, the average contract value of credit from other sources of the National Rural Credit System was R\$166,720.14 (BCB, 2019).
} 
Table 3. Estimates of unconditional quantile regression—PRONAF and credit from other sources, Brazil, 2014

\begin{tabular}{|c|c|c|c|c|c|}
\hline Ln(Yi) Dependent Variables & $\mathrm{q} 10$ & q25 & q50 & q75 & q90 \\
\hline \multirow[t]{2}{*}{ PRONAF } & $0.207^{\star \star \star}$ & $0.163^{\star \star \star}$ & $0.195^{\star \star \star}$ & $0.197^{\star \star \star}$ & 0.0379 \\
\hline & $(0.0332)$ & $(0.0318)$ & $(0.0272)$ & $(0.0392)$ & $(0.0619)$ \\
\hline \multirow[t]{2}{*}{ Other sources } & $0.133^{\star \star}$ & $0.198^{\star \star \star}$ & $0.177^{\star \star \star}$ & $0.544^{\star \star \star}$ & $0.875^{\star \star \star}$ \\
\hline & $(0.0604)$ & $(0.0469)$ & $(0.0389)$ & $(0.0580)$ & $(0.120)$ \\
\hline \multirow[t]{2}{*}{ Extension } & $0.121^{\star \star \star}$ & $0.200^{\star \star \star}$ & $0.202^{\star \star \star}$ & $0.340^{\star \star \star}$ & $0.455^{\star \star \star}$ \\
\hline & $(0.0305)$ & $(0.0274)$ & $(0.0240)$ & $(0.0353)$ & $(0.0587)$ \\
\hline \multirow[t]{2}{*}{ Gender } & $-0.108^{\star \star}$ & $-0.193^{\star \star \star}$ & -0.0333 & -0.0217 & 0.0524 \\
\hline & $(0.0431)$ & $(0.0297)$ & $(0.0224)$ & $(0.0248)$ & $(0.0356)$ \\
\hline \multirow[t]{2}{*}{ Race } & 0.0442 & -0.0374 & $-0.153^{\star \star \star}$ & $-0.118^{\star \star \star}$ & $-0.0965^{\star \star \star}$ \\
\hline & $(0.0634)$ & $(0.0448)$ & $(0.0309)$ & $(0.0298)$ & $(0.0360)$ \\
\hline \multirow[t]{2}{*}{ Incomplete elementary } & 0.547 & $0.381^{*}$ & -0.206 & $-0.229^{\star}$ & -0.00332 \\
\hline & $(0.338)$ & $(0.197)$ & $(0.133)$ & $(0.123)$ & $(0.0545)$ \\
\hline \multirow[t]{2}{*}{ Complete elementary } & $0.582^{*}$ & $0.439^{\star *}$ & -0.119 & -0.0656 & $0.199^{\star \star \star}$ \\
\hline & $(0.336)$ & $(0.196)$ & $(0.133)$ & $(0.123)$ & $(0.0533)$ \\
\hline \multirow[t]{2}{*}{ Incomplete high school } & $0.756^{\star *}$ & $0.551^{\star \star \star}$ & 0.00894 & 0.104 & $0.385^{\star \star \star}$ \\
\hline & $(0.338)$ & (0.199) & $(0.135)$ & $(0.128)$ & $(0.0730)$ \\
\hline \multirow[t]{2}{*}{ Complete high school } & $0.781^{\star *}$ & $0.694^{\star \star \star}$ & 0.0715 & $0.235^{\star}$ & $0.624^{\star \star \star}$ \\
\hline & $(0.346)$ & $(0.205)$ & $(0.139)$ & $(0.134)$ & $(0.104)$ \\
\hline \multirow[t]{2}{*}{ Incomplete higher education } & $0.724^{\star \star}$ & $0.737^{\star \star \star}$ & 0.203 & $0.295^{\star \star}$ & $0.664^{\star \star \star}$ \\
\hline & $(0.338)$ & $(0.198)$ & $(0.135)$ & $(0.127)$ & $(0.0755)$ \\
\hline \multirow[t]{2}{*}{ Complete higher education } & $0.831^{\star \star}$ & $0.728^{\star \star \star}$ & $0.394^{\star \star \star}$ & $0.942^{\star \star \star}$ & $1.990^{\star \star \star}$ \\
\hline & $(0.337)$ & $(0.200)$ & $(0.136)$ & $(0.135)$ & $(0.141)$ \\
\hline \multirow[t]{2}{*}{ Age $26-35$} & -0.0308 & -0.0988 & $-0.133^{\star \star \star}$ & $-0.0747^{\star}$ & 0.00594 \\
\hline & $(0.0902)$ & $(0.0610)$ & $(0.0408)$ & $(0.0397)$ & $(0.0609)$ \\
\hline \multirow[t]{2}{*}{ Age $36-45$} & $0.178^{\star \star}$ & $0.118^{\star *}$ & -0.0577 & -0.0165 & 0.0560 \\
\hline & $(0.0850)$ & $(0.0583)$ & $(0.0397)$ & $(0.0391)$ & $(0.0603)$ \\
\hline \multirow[t]{2}{*}{ Age $46-55$} & 0.0573 & $0.157^{\star \star \star}$ & 0.00464 & 0.0365 & 0.0787 \\
\hline & $(0.0859)$ & $(0.0582)$ & $(0.0400)$ & $(0.0400)$ & $(0.0625)$ \\
\hline \multirow[t]{2}{*}{ Age $56-65$} & $0.380^{\star \star \star}$ & $0.612^{\star \star \star}$ & $0.274^{\star \star \star}$ & $0.163^{\star \star \star}$ & $0.207^{\star \star \star}$ \\
\hline & $(0.0855)$ & $(0.0589)$ & $(0.0423)$ & $(0.0422)$ & $(0.0658)$ \\
\hline \multirow[t]{2}{*}{ Age 65 or higher } & $0.733^{\star * \star}$ & $1.002^{\star \star \star}$ & $0.711^{\star \star *}$ & $0.301^{\star \star \star}$ & $0.300^{\star \star \star}$ \\
\hline & $(0.0848)$ & $(0.0586)$ & $(0.0451)$ & $(0.0482)$ & $(0.0731)$ \\
\hline \multirow[t]{2}{*}{ Rural } & $-0.219^{\star \star \star}$ & $-0.288^{\star \star \star}$ & $-0.229 * \star \star$ & $-0.300^{\star \star \star}$ & $-0.325^{\star \star \star}$ \\
\hline & $(0.0316)$ & $(0.0239)$ & $(0.0186)$ & $(0.0222)$ & $(0.0341)$ \\
\hline \multirow[t]{2}{*}{ Partner } & -0.0326 & -0.00320 & $-0.186^{\star \star \star}$ & $-0.138^{\star \star \star}$ & $-0.106^{\star \star}$ \\
\hline & $(0.0652)$ & $(0.0494)$ & $(0.0341)$ & $(0.0370)$ & $(0.0529)$ \\
\hline
\end{tabular}


Table 3. (Continued)

\begin{tabular}{|c|c|c|c|c|c|}
\hline Ln(Yi) Dependent Variables & q10 & q25 & q50 & q75 & q90 \\
\hline \multirow[t]{2}{*}{ Tenant } & -0.0582 & 0.0252 & 0.0084 & -0.0350 & -0.0479 \\
\hline & $(0.0657)$ & $(0.0456)$ & $(0.0336)$ & $(0.0413)$ & $(0.0621)$ \\
\hline \multirow[t]{2}{*}{ Occupant } & 0.0483 & -0.0409 & $-0.0801^{\star}$ & -0.0564 & $-0.0910^{\star \star \star}$ \\
\hline & $(0.0835)$ & $(0.0639)$ & $(0.0415)$ & $(0.0347)$ & $(0.0350)$ \\
\hline \multirow[t]{2}{*}{ Other condition } & $-0.341^{\star \star \star}$ & $-0.0953^{\star \star}$ & $-0.152^{\star \star \star}$ & $-0.174^{\star \star \star}$ & $-0.0909^{\star \star}$ \\
\hline & $(0.0681)$ & $(0.0438)$ & $(0.0291)$ & $(0.0265)$ & $(0.0363)$ \\
\hline \multirow[t]{2}{*}{ Small } & $0.233^{\star \star \star}$ & $0.216^{\star \star \star}$ & $0.175^{\star \star \star}$ & $0.273^{\star \star \star}$ & $0.274^{\star \star \star}$ \\
\hline & $(0.0299)$ & $(0.0237)$ & $(0.0191)$ & $(0.0238)$ & $(0.0356)$ \\
\hline \multirow[t]{2}{*}{ Medium } & $0.151^{\star \star \star}$ & $0.153^{\star \star \star}$ & $0.197^{\star \star \star}$ & $0.492^{\star \star \star}$ & $0.840^{\star \star \star}$ \\
\hline & $(0.0485)$ & $(0.0388)$ & $(0.0310)$ & $(0.0413)$ & $(0.0769)$ \\
\hline \multirow[t]{2}{*}{ Large } & $0.199^{\star \star \star}$ & $0.207^{\star \star \star}$ & $0.164^{\star \star \star}$ & $0.202^{\star \star \star}$ & $0.383^{\star \star \star}$ \\
\hline & $(0.0519)$ & $(0.0469)$ & $(0.0406)$ & $(0.0512)$ & $(0.0834)$ \\
\hline \multirow[t]{2}{*}{ North } & $0.505^{\star \star \star}$ & $0.362^{\star \star \star}$ & $0.200^{\star \star \star}$ & $0.177^{\star \star \star}$ & $-0.0568^{\star \star}$ \\
\hline & $(0.0379)$ & $(0.0293)$ & $(0.0207)$ & $(0.0210)$ & $(0.0250)$ \\
\hline \multirow[t]{2}{*}{ Southeast } & $0.578^{\star \star \star}$ & $0.540^{\star \star \star}$ & $0.489^{\star \star \star}$ & $0.483^{\star * \star}$ & $0.258^{\star \star \star}$ \\
\hline & $(0.0411)$ & $(0.0324)$ & $(0.0265)$ & $(0.0334)$ & $(0.0490)$ \\
\hline \multirow[t]{2}{*}{ South } & $0.596^{\star \star \star}$ & $0.601^{\star \star \star}$ & $0.574^{\star \star \star}$ & $0.700^{\star \star \star}$ & $0.549^{\star \star \star}$ \\
\hline & $(0.0382)$ & $(0.0311)$ & $(0.0256)$ & $(0.0327)$ & $(0.0496)$ \\
\hline \multirow[t]{2}{*}{ Midwest } & $0.594^{\star \star \star}$ & $0.484^{\star \star \star}$ & $0.516^{\star \star \star}$ & $0.580^{\star \star \star}$ & $0.628^{\star \star \star}$ \\
\hline & $(0.0399)$ & $(0.0381)$ & $(0.0321)$ & $(0.0418)$ & $(0.0716)$ \\
\hline \multirow[t]{2}{*}{ Intercept } & $5.182^{\star \star \star}$ & $5.931^{\star \star \star}$ & $7.237^{\star \star \star}$ & $7.720^{\star \star \star}$ & $7.948^{\star \star \star}$ \\
\hline & $(0.347)$ & $(0.204)$ & (0.139) & $(0.132)$ & $(0.0844)$ \\
\hline Observations & & & 15,402 & & \\
\hline$R^{2}$ & 0.079 & 0.161 & 0.227 & 0.244 & 0.178 \\
\hline F-statistic & 40.76 & 107.5 & 203.7 & 186.7 & 60.80 \\
\hline
\end{tabular}

Notes: ${ }^{* \star *}$ significant at $1 \%,{ }^{* \star}$ significant at $5 \%,{ }^{*}$ significant at $10 \%$; standard errors in parentheses; Wald test indicated statistical difference, at a level of $1 \%$ of significance, between coefficients of covariates at different monthly income quantiles.

Source: Own elaboration.

schooling and access to rural extension explain nearly the entire income gap in these quantiles, especially from q75 and above (see Figure 4).

The return effect is steady over the distribution, except along the top quantiles. This implies that, for the top quantiles, the income differential is not explained by the difference on the return (effect on income) of household characteristics between those that had access to credit and those that did not, that is, for income quantiles lower than q75, the return effect is positive, which suggests that households that had access to credit obtained a higher return to household/individual characteristics on their income, such as education.

Figure 4 and Table 4 break down the composition effect. We found that access to rural extension, education, and the location of residence are the main factors explaining the higher level of income for farmers that had access to rural credit. This suggests a potential selection bias on the provision of rural credit, including PRONAF, which was also pointed out by Aquino and Schneider (2011). The negative influence of age and other characteristics (e.g., gender and race) 
Table 4. Decomposition of the income differentials: with rural credit and without rural credit, Brazil, 2014

\begin{tabular}{|c|c|c|c|c|c|}
\hline & $\mathrm{q} 10$ & q25 & q50 & q75 & q90 \\
\hline Income differential $[\ln (Y i)]$ & 0.5292 & 0.5900 & 0.5956 & 0.6302 & 0.5099 \\
\hline Composition effect & 0.3037 & 0.2554 & 0.2701 & 0.4586 & 0.7094 \\
\hline Return effect & 0.2255 & 0.3346 & 0.3255 & 0.1717 & -0.1994 \\
\hline \multicolumn{6}{|l|}{ Detailed composition effect } \\
\hline Schooling & 0.0353 & 0.0358 & 0.0404 & 0.0747 & 0.1338 \\
\hline Age & -0.0220 & -0.0229 & -0.0232 & -0.0083 & -0.0076 \\
\hline Extension & 0.0887 & 0.0873 & 0.0742 & 0.1502 & 0.2753 \\
\hline Farmer condition & 0.0077 & 0.0078 & 0.0171 & 0.0169 & 0.0189 \\
\hline Farm size & 0.0652 & 0.0437 & 0.0317 & 0.0606 & 0.1047 \\
\hline Region & 0.1478 & 0.1242 & 0.1391 & 0.1748 & 0.1917 \\
\hline Others ${ }^{\#}$ & -0.0191 & -0.0205 & -0.0092 & -0.0102 & -0.0075 \\
\hline \multicolumn{6}{|l|}{ Detailed return effect } \\
\hline Schooling & -1.9569 & -1.8952 & 1.0102 & 0.5400 & 0.2875 \\
\hline Age & 0.2065 & 0.0033 & -0.0931 & 0.3049 & 0.1860 \\
\hline Extension & -0.0049 & -0.0094 & -0.0242 & -0.1267 & -0.3386 \\
\hline Farmer condition & 0.0160 & -0.0241 & -0.0260 & 0.0025 & 0.0074 \\
\hline Farm size & 0.0502 & 0.0870 & 0.0805 & -0.0349 & -0.0902 \\
\hline Region & 0.2529 & 0.3910 & 0.1812 & -0.1969 & -0.2270 \\
\hline Others ${ }^{\#}$ & -0.2619 & -0.1446 & -0.0878 & 0.1462 & 0.1281 \\
\hline
\end{tabular}

Note: \#Includes Gender and Race.

Source: Own elaboration.

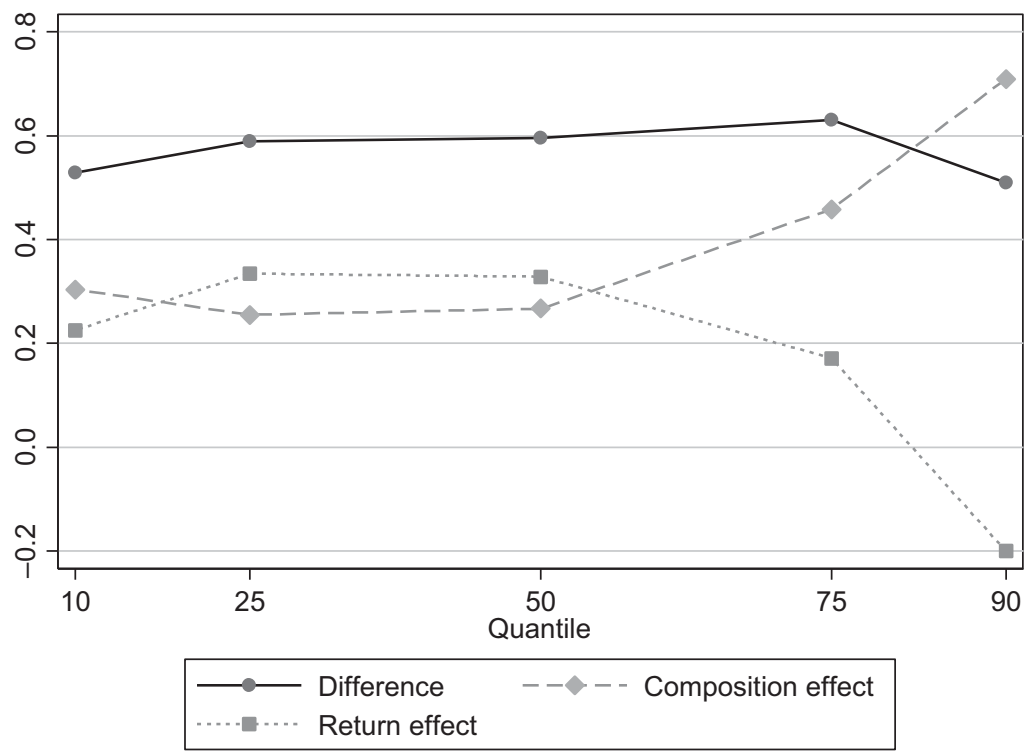

Figure 3. Decomposition of the income differential: with rural credit and without rural credit, Brazil, 2014. Source: Own elaboration. 


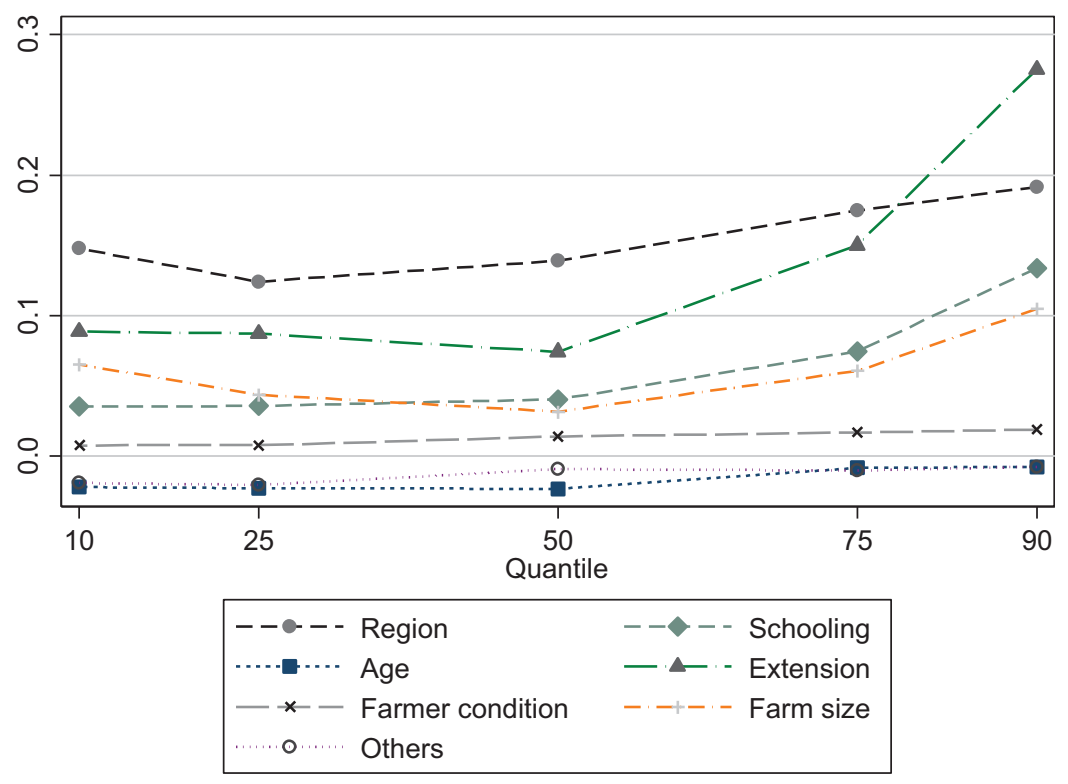

Figure 4. Detailed decomposition of the composition effect of income differential, Brazil, 2014. Source: Own elaboration.

indicate that these variables contribute to the reduction of income differential between farmers that had access to credit and those that did not. These results suggest that the effect of credit might be constrained for low-income farmers given the lack of education and access to rural extension. Higher education level also helps farmers to absorb information and implement technical recommendations more precisely (Freitas, 2017).

We also break down the return effect to better understand how the return to the characteristics affects household income (see Table 4). Although we observed an erratic influence of schooling on rural income, this variable contributes considerably to income in the two highest income quantiles (q75-q90). This result might be associated with the lower presence of farmers with high schooling levels in these quantiles, which leads to a higher return for this variable (marginal effect). The exact opposite is true for the lowest quantiles (q10-q50). In general, most of the variables have a similar influence on income differentials.

\subsection{Regional analysis}

Regional disparities remain a strong factor in Brazilian rural areas, as suggested by Azzoni (2001), Alves et al. (2013), and Costa et al. (2016). Figure 5 presents regional differences in income gap focusing on the return effect-the most prominent influence in the comparison between the regions. The models were re-estimated for selected pairs of Brazilian regions. The results suggest that a household in the Northeast region would obtain a much greater income effect from access to credit if they had the same characteristics as households in the Southeast, though not necessarily with a reduction in income inequality. A similar trend was observed in the comparison between the Northeast and South regions: if Northeastern farmers had the same characteristics as Southern farmers, they would obtain a greater income but now with an important influence of decreasing income inequality in Northeastern rural area. 

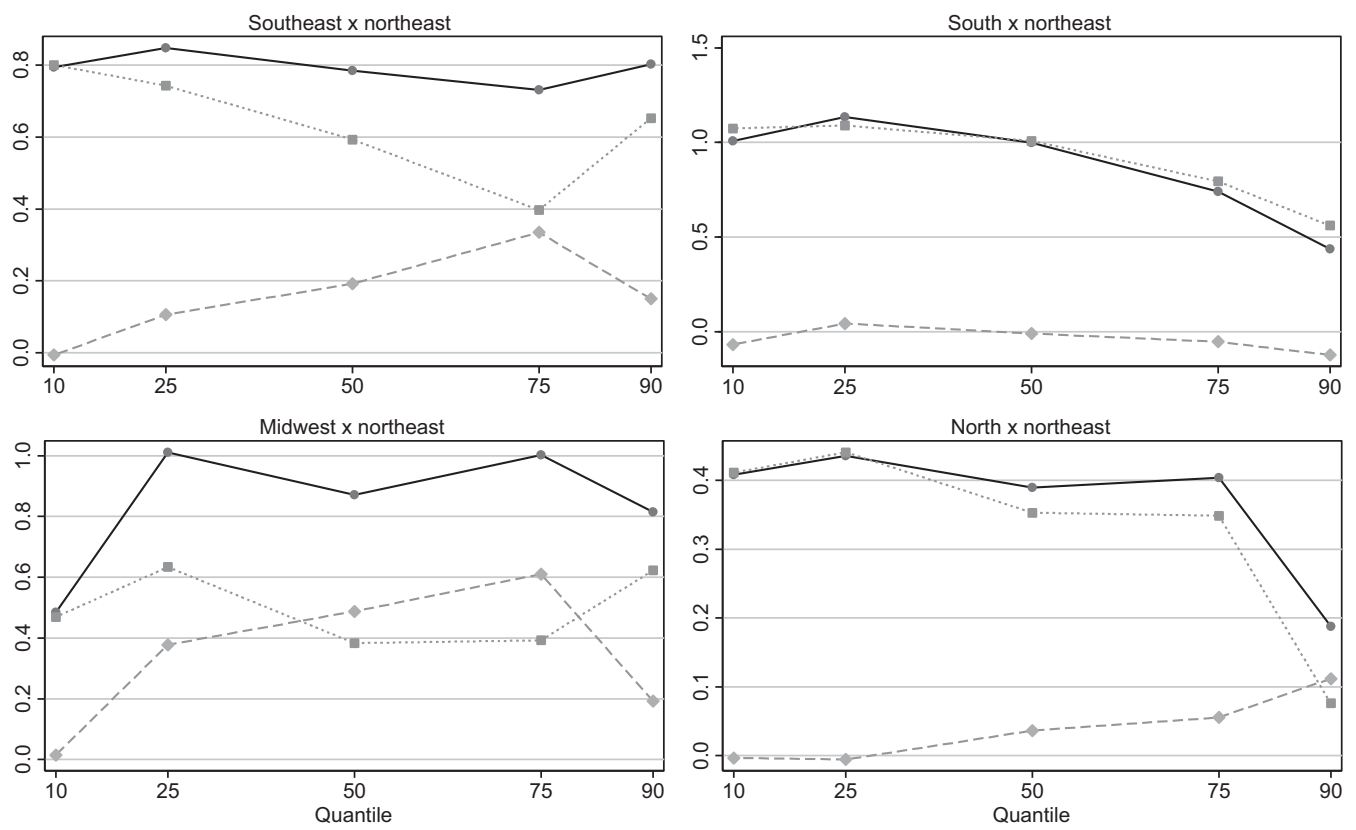

$\begin{array}{lll}\longrightarrow- & \text { Difference } & --\diamond-- \text { Composition effect } \\ \cdots \cdots & \text { Return effect }\end{array}$

Figure 5. Decomposition of the income differential: With rural credit—without rural credit, selected regions, Brazil, 2014. Source: Own elaboration.

\section{Concluding remarks}

The Brazilian agriculture segment has been growing exponentially in recent decades and has expanded its international market participation. However, Brazil continues to face a high level of rural inequality. In this paper, we sought to identify whether access to credit deepens or reduces inequality among rural households in Brazil. To obtain the effect of credit on household income, we used an income decomposition proposed by Firpo et al. (2007) and the household survey of 2014 from the IBGE (National Household Sample Survey_PNAD).

Our results suggested that Brazilian rural credit policy was capable of increasing rural household income in all income quantiles, but this also increased income inequality. However, we observed a smaller influence of PRONAF on increasing inequality. Additionally, we found that the rural credit from other sources has a greater effect on rural income in the top income quantiles. An income differential decomposition has demonstrated that the difference in individual characteristics explains most of the income differential in the upper portion of the income distribution.

The results of the present study indicate that a higher level of education and access to rural extension may be associated with a greater influence of rural credit on household income, which implies that access to rural credit alone cannot raise the social welfare of low-income farmers. Our findings suggest that the design of a joint public policy incorporating rural credit, rural extension, and the promotion of human capital would have much a stronger effect on reducing income inequality in the rural areas of Brazil. This suggests the existence of synergy between public policies and public services linked to rural credit.

Additionally, it is important to note that the Northeast region of Brazil should receive greater focus in the context of receiving beneficial extension services and human capital increase policies. This would allow its farmers to perform similarly to farmers in the South and Southeast regions, which would boost the result of rural credit programs in this region. 
Financial disclosure. This was supported by Climate Policy Initiative (CPI) in Brazil through a seed grant under the Land Use Initiative (Iniciativa pelo Uso da Terra-INPUT).

Conflicts of interest. None.

\section{References}

Alves, E.. "Reflexões sobre política agrícola." Revista de Economia e Sociologia Rural, 31,24(1993):91-102.

Alves, E., G.D.S. Souza, and D.D.P. Rocha. "Desigualdade nos campos na ótica do Censo Agropecuário 2006." Revista de Política Agrícola, 22,2(2013):67-75.

Aquino, J.R., and S. Schneider. "12 Anos da política de crédito do Pronaf no Brasil (1996-2008): Uma reflexão crítica." Revista de Extensão e Estudos Rurais, 1,2(2011):309-349.

Araújo, J.A., D.G. Feitosa, and F.A.F.D. Barreto. "Determinantes da desigualdade de renda em áreas rurais do Nordeste." Revista de Política Agrícola, 17,4(2008):65-82.

Araújo, P.F.C. Política de crédito rural: Reflexões sobre a experiência brasileira (No. 1555). Discussion paper, Instituto de Pesquisa Econômica Aplicada (IPEA), 2011.

Assunção, J., and F. Chein. "Condições de crédito no Brasil rural." Revista de Economia e Sociologia Rural, 45,2(2007): 367-407.

Azzoni, C.R. "Economic growth and regional income inequality in Brazil." The annals of regional science 35,1(2001): 133-152.

Bacha, C.J.C., L. Danelon, and E.D. Bel Filho. "Evolução da taxa de juros real do crédito rural no Brasil: período de 1985 a 2003.” Teoria e Evidência Econômica 14,26(2005):43-69.

Barros, R., M. de Carvalho, S. Franco, and R. Mendonça. "Uma análise das principais causas da queda recente na desigualdade de renda brasileira." Revista Econômica 8,1(2006):117-147.

Batista, H.R., and H.D. Neder. "Efeitos do Pronaf sobre a pobreza rural no Brasil (2001-2009)." Revista de Economia e Sociologia Rural 52(2014):147-166.

BCB. Banco do Brasil. Matriz de Dados do Crédito Rural. Internet site: http://www.bcb.gov.br/pt-br/\#!/c/MICRRURAL/ (Accessed November 22, 2019).

Besley, T. "Property rights and investment incentives: Theory and evidence from Ghana." Journal of Political Economy 103,5(1995):903-937.

Bianchini, V. Vinte anos do Pronaf, 1995-2015: avanços e desafios. Brasília: SAF/MDA, 2015.

BNDES. Banco Nacional de Desenvolvimento Econômico e Social. Programa Nacional de Fortalecimento da Agricultura Familiar, 2015. Internet site: http://www.bndes.gov.br/apoio/pronaf.html (Accessed December 21, 2017).

Buainain, A.M., A. Carlos, C. Santana, F. Silva, J. Garcia, and P. Loyola. “O tripé da política agrícola brasileira Crédito rural, seguro e Pronaf. In Buainain, Antônio Márcio et al." O mundo rural no Brasil do século 21,(2014):829-888.

Chi, W., and B. Li. "Glass ceiling or sticky floor? Examining the gender earnings differential across the earnings distribution in urban China, 1987-2004." Journal of Comparative Economics 36,2(2008):243-263.

Corrêa, V.P., and F.F. Silva. "O novo desenho do Financiamento Agrícola e as dificuldades para os produtores não integrados." Paper presented at the 42th Congress of SOBER - Sociedade Brasileira de Economia, Administração e Sociologia Rural [Brazilian Society of Economy, Administration and Rural Sociology], Cuiabá, Mato Grosso, Brazil, 2004.

Costa, R.A., E.M. Costa, and F.Z. Mariano. "Diferenciais de rendimentos nas áreas rurais do Brasil." Revista de Politica Agrícola 25,4(2016):112-135.

DiNardo, J., N.M. Fortin, and T. Lemieux. "Labor Market Institutions and the Distribution of Wages, 1973-1992: A Semiparametric Approach.” Econometrica 64,5(1996):1001-1044.

Ely, R.A., R. Parfitt, A. Carraro, and F.G. Ribeiro. "Rural credit and the time allocation of agricultural households: the case of Pronaf in Brazil." Paper presented at the 45th Brazilian Economics Meeting, ANPEC-Associação Nacional dos Centros de Pós-graduação em Economia [Brazilian Association of Post-Graduate Programs in Economics], Natal, Rio Grande do Norte, Brazil, December 12-15, 2017.

Feijó, R. "The impact of a family farming credit programme on the rural economy of Brazil." Paper presented at the 29th Brazilian Economics Meeting, ANPEC-Associação Nacional dos Centros de Pós-graduação em Economia [Brazilian Association of Post-Graduate Programs in Economics], Salvador, Bahia, Brazil, December 11-14, 2001.

Ferraz, O.G., H.L. Pase, S. Brandao, O.G. Ferraz, and L.C. Balcewicz. "Microcrédito rural: Análise sobre a modalidade do Pronaf B.” Paper presented at the 46th Congress, SOBER - Sociedade Brasileira de Economia, Administração e Sociologia Rural [Brazilian Society of Economy, Administration and Rural Sociology], Rio Branco, Acre, Brazil, July 20-23, 2008.

Firpo, S. "Efficient semiparametric estimation of quantile treatment effects." Econometrica 75,1(2007):259-276.

Firpo, S., N.M. Fortin, and T. Lemieux. "Unconditional quantile regressions.” Econometrica 77,3(2009):953-973.

Freitas, C.O. "Three Essays on the Effect of Rural Extension in the Brazilian Agricultural Sector." Ph.D. dissertation, Federal University of Viçosa, 2017. 
Garcias, M.O., and A.L. Kassouf. "Assessment of rural credit impact on land and labor productivity for Brazilian family farmers.” Nova Economia 26,3(2016):721-746.

Grisa, C., V.J. Wesz Junior, and V.D. Buchweitz. "Revisitando o Pronaf: velhos questionamentos, novas interpretações." Revista de Economia e Sociologia Rural 52,2(2014):323-346.

Guanziroli, C.E. "Pronaf dez anos depois: resultados e perspectivas para o desenvolvimento rural." Revista de economia e sociologia rural 45,2(2007):301-328.

Hartarska, V., D. Nadolnyak, and X. Shen. "Agricultural credit and economic growth in rural areas." Agricultural Finance Review 75,3(2015):302-312.

Helfand, S., R. Rocha, and H. Vinhais. "Pobreza e desigualdade de renda no Brasil rural: uma análise da queda recente." Pesquisa e Planejamento Econômico 39,1(2009):59-80.

IBGE. Instituto Brasileiro de Geografia e Estatística. Microdados da Pesquisa Nacional por Amostra de Domicílios (PNAD). Internet site: http://www.ibge.gov.br/ (Accessed December 21, 2017).

Jann, B. “A Stata implementation of the Blinder-Oaxaca decomposition." Stata Journal 8,4(2008):453-479.

Kageyama, A. "Produtividade e renda na agricultura familiar: efeitos do Pronaf-crédito." Agricultura em São Paulo 50,2(2003):1-13.

Koenker, R., and G. Basset. "Regression Quantiles." Econometrica 46,1(1978):33-50.

Leite, S.P. “Análise do financiamento da política de crédito rural no Brasil (1980-1996)." Estudos Sociedade e Agricultura 9,1(2013):129-163.

Luan, D.X., and S. Bauer. "Does credit access affect household income homogeneously across different groups of credit recipients? Evidence from rural Vietnam.” Journal of Rural Studies 47(2016):186-203.

Machado, J.A., and J. Mata. "Counterfactual decomposition of changes in wage distributions using quantile regression." Journal of applied Econometrics 20,4(2005):445-465.

Mahjabeen, R. "Microfinancing in Bangladesh: Impact on households, consumption and welfare." Journal of Policy Modeling 30,6(2008):1083-1092.

Oliveira, R.C., and R.D.M. Silveira Neto. “Afinal, Quão Importantes são as Desigualdades de Escolaridade para Explicar as Disparidades Regionais de Renda no Brasil?.” Paper presented at the 43th Brazilian Economics Meeting, ANPECAssociação Nacional dos Centros de Pós-graduação em Economia [Brazilian Association of Graduate Programs in Economics], Florianópolis, Santa Catarina, Brazil, December 8-11, 2015.

Reis, C.V.S., T.B.S. Moreira, and G.H.M. Cunha. "O efeito marginal do capital humano na agricultura familiar." Revista Espacios 38,23(2017):8.

Santana, C.A.M., A.M. Buainain, F.P. Silva, J.R. Garcia, and P. Loyola. "Política agrícola: Avanços e retrocessos ao longo de uma trajetória positiva. In Buainain, Antônio Márcio et al.“ O mundo rural no Brasil do século 21(2014):795-792.

Silva, V.H.M.C., and J.M.S. de França. "Decompondo o diferencial regional de salários entre Sudeste e Nordeste: uma aplicação da abordagem quantílica incondicional.” Revista Econômica do Nordeste 47,3(2017):109-129.

Soares, F.V., R.P. Ribas, and R.G. Osório. "Evaluating the impact of Brazil's Bolsa Familia: Cash transfer programs in comparative perspective." Latin American Research Review 45,2(2010):173-190.

Souza, P.M.D., N.J. Ponciano, M.G. Ney, and A. Fornazier. “Análise da Evolução do Valor dos Financiamentos do PronafCrédito (1999 a 2010): número, valor médio e localização geográfica dos contratos.” Revista de Economia e Sociologia Rural 51,2(2013):237-254.

Vega, C. "Comportamiento de los acreedores agropecuarios al racionar el credito: la lei de hierro de las restricciones a las tasas de interes." Crédito agrícola y desarrollo rural: la nueva visión. Adams, Dale W. et al., eds. Columbus, OH: The Ohio State University, 1987.

Wan, G., and Z. Zhou. "Income Inequality in Rural China: Regression-based Decomposition Using Household Data." Review of Development Economics 9,1(2005):107-120.

Cite this article: Neves MCR, Freitas CO, Silva FF, Costa DRM, and Braga MJ (2020). Does Access to Rural Credit Help Decrease Income Inequality in Brazil? Journal of Agricultural and Applied Economics 52, 440-460. https://doi.org/10.1017/aae.2020.11 